\title{
TWO MYTHS OF ADMINISTRATIVE LAW
}

\author{
MARK P. MANCINI
}

\section{INTRODUCTION}

Administrative lawyers are accustomed to a constant redesign of the chapters of the administrative law story. On schedule, the law is due for yet another retelling in a series of cases to be heard by the Supreme Court of Canada. ${ }^{1}$ Despite this frequent recasting, Canada's law of judicial review cannot rid itself of some persistent myths that defy explanation.

In this paper, I catalogue two myths that are inconsistent with the fundamental principle of the Canadian law of judicial review, what I call the "policing function" of the courts. ${ }^{2}$ The policing function is a reconciliation of the "underlying tension" between legislative supremacy and the rule of law. ${ }^{3}$ It provides that courts on judicial review of administrative interpretations of law must apply the ordinary tools of statutory interpretation, which determine the margin of appreciation available to the decisionmaker. In this sense, part of the law to be enforced is the standard of review, ${ }^{4}$ a matter of "legislative intent." Problematically, the myths encourage the courts to turn away from this fundamental task and instead determine the standard of review based on external criteria. These criteria may impose a different standard of review than the one specified by the legislature. ${ }^{6}$

In Part I, I explain the policing function, its development, and why it is the fundamental principle of administrative law. Inherited from British law, it finds force in

Copyright $\odot 2019$ by MARK P. MANCINI.

* JD (UNB, 2017), LLM (Chicago, 2019). The author wishes to express his love and appreciation to Jerica Almonte for her continued support.

${ }^{1}$ Minister of Citizenship and Immigration v Alexander Vavilov (2018), leave to appeal to SCC granted, 37748 (10 May 2018); Bell Canada v AG Canada (2018), leave to appeal to SCC granted, 37896 (10 May 2018); National Football League v AG Canada (2018), leave to appeal to SCC granted, 37897 (10 May 2018).

${ }^{2}$ I will describe the heritage of this policing function in Part I, below. For now, it suffices to say that this function finds support in the case law. See Cote J's comment in West Fraser Mills Ltd v British Columbia (Workers' Compensation Appeal Tribunal), 2018 SCC 22 at para 59: "In this context, respect for legislative intent - a cornerstone of judicial review—requires that courts accurately police the boundaries of delegated power."

${ }^{3}$ Dunsmuir v New Brunswick, 2008 SCC 9 at para 27 [Dunsmuir].

${ }^{4}$ See $R v$ Owen, 2003 SCC 33.

${ }^{5}$ Dunsmuir, supra note 3 at para 30.

${ }^{6}$ I should note that my focus is not directed towards statutes that explicitly set the standard of review for all decision-makers. See e.g. Administrative Tribunals Act, SBC 2004, c 45, ss 58-59. Rather, I am interested in situations where courts must determine the standard of review applicable to a decisionmaker on a specific decision, with reference to the organic statute of the decision-maker. 
present-day Canadian administrative law, even in the era of deference. I will also explain how the myths are generally inconsistent with the policing function and address the main criticisms of the view I adopt.

In Parts II and III, I lay out the two myths: (1) administrative decision-makers have expertise in matters of statutory interpretation and (2) jurisdictional questions can be usefully identified. These myths have the potential to mandate a different standard of review than the one indicated by the legislature, contrary to the direction in Dunsmuir that judicial review should only follow "where justice requires it, but not otherwise."7 These myths should be abandoned in an effort to encourage courts to return to the fundamental notion that all aspects of the administrative state-including the standard of review-are rooted in statute. ${ }^{8}$

Identifying these myths is important, regardless of the Supreme Court's decision in its upcoming trilogy of cases in which the nature and scope of judicial review will be revisited. Judicial review is still plagued by "superfluous discussions and processes" that obscure the statutory roots of administrative decision-makers and the supervisory role of courts. ${ }^{9}$ All administrative law "operational rules," 10 including the intensity of review, should be deduced from the policing function. As the myths are inconsistent with the policing function, they should be banished from the world of administrative law.

\section{THE FUNDAMENTAL BASIS OF CANADIAN ADMINISTRATIVE LAW}

\section{Explaining the Policing Function and Its History}

The Supreme Court has accepted the policing function as a central component of the law of judicial review. Most notably, Dunsmuir recognized that the task of courts on judicial review is to "supervise those who exercise statutory powers, to ensure that they do not overstep their legal authority." 11 Because statutory regimes confine the authority of administrative decision-makers, judicial review is concerned with determining "what authority was intended to be given to the body in relation to the subject matter." 12 The court acknowledged in Dunsmuir, as well as in other cases, ${ }^{13}$ that the policing function is

\footnotetext{
${ }^{7}$ Supra note 3 at para 43.

${ }^{8}$ Ocean Port Hotel Ltd v British Columbia (General Manager, Liquor Control and Licensing Branch), 2001 SCC 52, McLachlin CJC ("[a]dministrative tribunals, by contrast, lack [the] constitutional distinction from the executive. They are, in fact, created precisely for the purpose of implementing government policy" at para 24).

${ }^{9}$ See Deschamps J's opinion in Dunsmuir, supra note 3 at paras 158-59.

${ }^{10}$ See David Stratas, “A Decade of Dunsmuir: Please No More” (8 March 2018), online (blog): Paul Daly: Administrative Law Matters <www.administrativelawmatters.com/blog/2018/03/08/a-decade-ofdunsmuir-please-no-more-hon-david-w-stratas> [Stratas, “A Decade of Dunsmuir”].

${ }^{11}$ Dunsmuir, supra note 3 at para 28.

12 Ibid at para 29.

${ }^{13}$ Highwood Congregation of Jehovah's Witnesses (Judicial Committee) v Wall, 2018 SCC 26 [Wall], Rowe J ("[j]udicial review is a public law concept that allows s. 96 courts to "engage in surveillance of
} 
a constitutional duty ${ }^{14}$ "to ensure that public authorities do not overreach their lawful powers." 15 In essence, the policing function is the way in which the principles of parliamentary sovereignty and the rule of law are reconciled-in fact, they are not in conflict to begin with.

The policing function is an important part of the development of Canada's administrative law because it is the way in which the rule of law and the British notion of parliamentary sovereignty synthesize. On the one hand, the British idea of parliamentary sovereignty provided that Parliament had the power "to make or unmake any law whatever." 16 The English Bill of Rights enshrined the principle that, absent constitutional objection, legislation binds all. ${ }^{17}$ Therefore, courts gave effect to legislation "no matter how preposterous its content." 18 Under the British model, Parliament was seen as the guarantor of liberties of the people; through ordinary law, the people and government were equally bound by law (at least theoretically). On the other hand, the rule of law grounds the power of courts to supervise statutory creations of Parliament. The rule of

\footnotetext{
lower tribunals' in order to ensure that these tribunals respect the rule of law" at para 13); Dunsmuir, supra note 3, Bastarache and LeBel JJ ("[a]dministrative powers are exercised by decision makers according to statutory regimes that are themselves confined. A decision maker may not exercise authority not specifically assigned to him or her. By acting in the absence of legal authority, the decision maker transgresses the principle of the rule of law. Thus, when a reviewing court considers the scope of a decision-making power or the jurisdiction conferred by a statute, the standard of review analysis strives to determine what authority was intended to be given to the body in relation to the subject matter" at para 29); Edmonton (City) v Edmonton East (Capilano) Shopping Centres Ltd, 2016 SCC 47 [Edmonton East], Karakatsanis J ("[t]he Dunsmuir framework balances two important competing principles: legislative supremacy, which requires the courts to respect the choice of Parliament or a legislature to assign responsibility for a given decision to an administrative body; and the rule of law, which requires that the courts have the last word on whether an administrative body has acted within the scope of its lawful authority" at para 21).

${ }^{14}$ Syndicat des employés de production du Québec v CLRB, [1984] 2 SCR 412 at 444; see also UES, Local 298 v Bibeault, [1988] 2 SCR 1048 [Bibeault], Beetz J ("[t]he role of the superior courts in maintaining the rule of law is so important that it is given constitutional protection" at para 126); Crevier $v A G$ (Quebec), [1981] 2 SCR 220 [Crevier], Laskin CJ ("a provincially-constituted statutory tribunal cannot constitutionally be immunized from review of decisions on questions of jurisdiction" at 236).

${ }^{15}$ Dunsmuir, supra note 3 at para 29.

${ }^{16}$ Albert V Dicey, Introduction to the Study of the Law of the Constitution, 10th ed (London: Macmillan Education Ltd, 1985) at 39 [Dicey].

${ }^{17} 1$ Will \& Mar sess 2, c 2 (Eng, 1689).

${ }^{18}$ Stanley A De Smith, Constitutional and Administrative Law, 7th ed by Rodney Brazier (London: Penguin Books, 1994).
} 
law, ${ }^{19}$ though "essentially contested," ${ }^{20}$ provides at the very least ${ }^{21}$ that no one is above the law, even government officials. The courts must enforce Parliament's law against its own statutory delegates: broadly construed, members of the "administrative state.", 2 Therefore, all administrative action must be grounded in law, and courts must police the boundaries of the administrative state under any standard of review.

While Parliament's powers have historically been extensive in this respect, they were not limitless when it came to empowering so-called "statutory delegates." The inherent jurisdiction of superior courts, inherited from Britain, allowed the courts to intervene. The prerogative writs, most notably certiorari, ${ }^{23}$ allowed aggrieved parties to challenge the substantive legality of governmental decisions. ${ }^{24}$ Blackstone's 1765 exposition on the laws of England noted that the prerogative writ of certiorari was designed to "keep all inferior jurisdictions within the bounds of their authority ... [protecting] the liberty of the subject, by speedy and summary interposition." 25 Dicey placed Blackstone's comments in the context of the rule of law and the English Constitution, arguing that no matter how capacious the powers granted by a legislature, there are dual protections against the arbitrary exercise of power. First is the control of the statute itself, which fences in administrative discretion; second is the interpretation by common law courts on the powers of the policing function. ${ }^{26}$

\footnotetext{
${ }^{19}$ I pause to note that this paper is not an extensive commentary on the content or normative quality of the rule of law, nor its historical and contemporary development. There are various accounts of the rule of law in the Canadian context, some of which are canvassed in at least three important papers: Mary Liston, "Governments in Miniature: The Rule of Law in the Administrative State," in Colleen Flood \& Lorne Sossin, eds, Administrative Law In Context (Toronto: Emond Montgomery, 2008) [Liston]; David Dyzenhaus, "The Deep Structure of Roncarelli v Duplessis" (2004) 53 UNBLJ 111 at 124; David Dyzenhaus, "Constituting the Rule of Law: Fundamental Values in Administrative Law" (2002) 27 Queen's LJ 445 [Dyzenhaus, “Constituting”].

${ }^{20}$ Liston, supra note 19 at 78.

${ }^{21}$ See ibid at 40-43 where the author argues that the principle of "legality" is the "core of meaning" of the rule of law in legal theory. To Liston, legality "should always authorize the use of and constrain the risk of the arbitrary use of public power." Liston notes that legality is the basic notion of the rule of law that finds expression in the accounts of three main theorists on the rule of law: Albert V Dicey, Lon Fuller, and Joseph Raz. Liston's comments support the minimal rule of law requirement that all state action must be authorized by law. The rule of law can mean many things, but it means at least this. ${ }^{22}$ This is an imprecise term, because the "administrative state" is virtually endless in size in today's modern government. Be that as it may, I use the term to denote adjudicative and policy-making bodies acting under statutory authority.

${ }^{23}$ See Gus Van Harten et al, Administrative Law: Cases, Text, and Materials, 7th ed (Toronto: Emond Montgomery, 2015) at 930 [Van Harten], where the prerogative writ of certiorari is explained.

${ }^{24}$ Ibid: "In essence, certiorari and the other prerogative writs ... were vehicles for ensuring that the administrative arms of government were kept under control."

${ }^{25}$ William Blackstone, Commentaries on the Laws of England, Volume 3 (Oxford: Clarendon Press, 1765-69) at 42.

${ }^{26}$ Dicey, supra note 16.
} 
Although Dicey himself has been subject to much criticism, ${ }^{27}$ the policing function as he set it out is accepted in any conception of the rule of law-as a matter of what Liston calls the principle of "legality." 28 This principle is the centerpiece of the interaction between parliamentary sovereignty and the rule of law, which defines the policing function. Parliament is entitled to delegate power to administrative decisionmakers subject to constitutional limits, but that delegation cannot purport to oust the ability of courts to determine the law to which the delegate is subject. As such, courts determine whether the delegation of power is properly exercised by decision-makers in the context of judicial review proceedings. On this account, parliamentary sovereignty and the rule of law are two sides of the same coin, bound by the policing function.

Canadian constitutional law adopts this understanding of the policing function. The preamble to the Constitution Act, 1867 states that Canada will have a Constitution "similar in principle to that of the United Kingdom," 29 which incorporates the rule of law principle. The rule of law appears explicitly in the preamble to the Constitution Act, 1982, which states that "Canada is founded upon principles that recognize the supremacy of God and the rule of law." ${ }^{30}$ Specifically, respecting legislative supremacy, the preamble of the Constitution Act, 1867 gives Parliament and the legislatures the exclusive right to legislate in respect of specific matters. Consistent with this text, the Supreme Court has accepted the role of the rule of law as an underlying constitutional principle ${ }^{31}$ of which the Supreme Court is the guardian. ${ }^{32}$ In this sense, the rule of law and parliamentary sovereignty are constitutional precepts, which the court views as informing the judicial review function.

This is perhaps best illustrated in the well-known example of Roncarelli $v$ Duplessis. ${ }^{33}$ Frank Roncarelli, a Jehovah's Witness and restaurant owner, had his liquor licence revoked (ostensibly due to his advocacy activities on behalf of Jehovah's Witnesses) on the order of Maurice Duplessis, premier and Attorney General of Quebec. Quebec legislation provided that only the chairperson of the Quebec Liquor Commission could revoke licences. The court held that Duplessis had stepped outside the bounds of his power as attorney general by stepping into the shoes of the chairperson. Further, the decision was based on extraneous factors to the relevant statute. ${ }^{34}$ This is a

\footnotetext{
${ }^{27}$ See Liston, supra note 19 at 85; Van Harten, supra note 23 at 25.

${ }^{28}$ Liston, supra note 19 at 80.

${ }^{29}$ Preamble to the Constitution Act, 1867 (UK), 30 \& 31 Vict, c 3.

${ }^{30}$ Preamble to the Constitution Act, 1982, being Schedule B to the Canada Act 1982 (UK), 1982, c11.

${ }^{31}$ Reference Re Secession of Quebec, [1998] 2 SCR 217 at para 71; Reference Re Manitoba Language Rights, [1985] 1 SCR 721 at 747-52.

${ }^{32}$ Hunter $v$ Southam Inc, [1984] 2 SCR 145 at 155.

33 [1959] SCR 121 [Duplessis].

${ }^{34}$ Liston, supra note 19 at 88.
} 
straightforward application of the policing function and the ultra vires doctrine. ${ }^{35}$ Because Duplessis did not have statutory power to make the decision, and made it contrary to law at any rate, it was unlawful.

While Duplessis is an example of the policing function, the rationale adopted by the majority of the Supreme Court is decidedly Diceyan. ${ }^{36}$ Justice Rand's classic concurring opinion is a more modern application of the policing function as applied in administrative law. Justice Rand's opinion is often cited as an example of a more "substantive" application of the rule of law $^{37}$ because it recognizes that even if a statutory grant is broad, a decision could offend the rule of law if it is made contrary to relevant statutory purposes or other values of the legal system. At its root, however, it is an example of the policing function, just as the majority's opinion is. Whether the decision is unlawful because it was not authorized by law or the decision is invalid because it is disconnected from a statutory purpose, the same question must be considered: does the decision comport with the enabling statute? On the logic of each opinion, it is the job of the court to enforce the law of the legislature, no matter the level of abstraction of Duplessis' violation.

The case law on superior courts, often referred to as "section 96 courts," provides a further example of the policing function in administrative law. As noted above, Parliament and the provincial legislatures each have the exclusive power to legislateand that legislation includes the delegation of powers to statutory creations. But notably, section 96 of the Constitution Act, 1867 (which constitutionalizes the power of the federal government to appoint provincial superior court judges) provides a substantive limitation on this delegatory power. ${ }^{38}$ Since superior courts have a core supervisory jurisdiction over inferior tribunals, ${ }^{39}$ that power cannot be fully ousted by legislatures. ${ }^{40}$ The power of courts to police the boundaries of legislative delegations is preserved constitutionally, but that power similarly ensures that Parliament's law is vindicated-that the level of deference owed to decision-makers in legislative language is respected. Legislative supremacy and the rule of law find agreement.

The policing function is a relatively uncontroversial foundation for administrative law in Canada. Those who are inclined to support deference for decision-makers can feel comfortable that courts will give effect to Parliament's intent to delegate power to decision-makers. At the same time, those who worry about the breadth of the

\footnotetext{
${ }^{35}$ The ultra vires doctrine, a natural corollary of Diceyan principles, allows courts to enforce statutory boundaries and declare unlawful the acts of state agents that are "beyond" their powers under enabling legislation: see Paul P Craig, "The Nature and Purpose of Administrative Law" in Administrative Law, 5th ed (London: Sweet \& Maxwell, 2003) at 3.

${ }^{36}$ Liston, supra note 19 at 88.

${ }^{37}$ Ibid at 89.

${ }^{38}$ McEvoy v AG for New Brunswick, [1983] 1 SCR 704 [McEvoy].

${ }^{39}$ MacMillan Bloedel Ltd $v$ Simpson, [1995] 4 SCR 725 at paras 33-34 [MacMillan Bloedel].

${ }^{40}$ Crevier, supra note 14 at 236-37.
} 
administrative state will look to courts to enforce Parliament's law against decisionmakers to ensure legality. The policing function is a resolution of the alleged tension between these two principles. Dunsmuir recognized this as the stable constitutional foundation of judicial review. ${ }^{41}$ However, this stable foundation has not turned into similarly stable doctrinal rules.

\section{The Problem with the Myths and Criticisms}

Disagreement arises as to how intensely courts should conduct the policing function. This is commonly known as the standard of review-just how "fussy" the courts should be on review. ${ }^{42}$ The standard of review is part of the law the courts must enforce on judicial review because legislatures may implicitly set the standard of review. ${ }^{43}$ However, the myths carry a fatal potential: the chance that they could demand a different intensity of review than the one mandated by the text, context, and purpose of the statute. This is because the myths look to factors that exist outside of the decision-maker's enabling statute. By doing so, the policing function is relaxed by deferring (or not) on the basis of non-statutory indicia ${ }^{44}$ rather than properly considering the accepted indicators of legislative intent. ${ }^{45}$

The standards of review were created in Dunsmuir around the proposition that the "rule of law" and "legislative supremacy" are necessarily in tension in all instances of

judicial review. ${ }^{46}$ But in ordinary cases of judicial review, there is no such tension. ${ }^{47}$ This is because when courts police the boundaries of administrative decision-makers' statutes, they vindicate the rule of law while imposing the democratically enacted law on the decision-makers. The fundamental question is whether the enabling statute mandates or

\footnotetext{
${ }^{41}$ Dunsmuir, supra note 3 at para 32.

${ }^{42}$ Stratas, "A Decade of Dunsmuir," supra note 10.

${ }^{43}$ See Pushpanathan v Canada (Minister of Citizenship and Immigration), [1998] 1 SCR 982

[Pushpanathan], Bastarache $\mathrm{J}$ ("[ $\mathrm{t}]$ he central inquiry in determining the standard of review exercisable by a court of law is the legislative intent of the statute creating the tribunal whose decision is being reviewed" at para 26); Canadian Union of Public Employees v Ontario (Minister of Labour), 2003 SCC 29, Binnie J (courts must seek the "polar star of legislative intent" at para 149); see also Tervita Corp $v$ Canada (Commissioner of Competition), 2015 SCC 3 at para 39.

${ }^{44}$ This practice is accepted by the Supreme Court of Canada. See Canada (Citizenship and Immigration) v Khosa, 2009 SCC 12 at paras 25-26 [Khosa].

${ }^{45}$ See Williams $v$ Canada (Public Safety and Emergency Preparedness), 2017 FCA 252 [Williams] for a description of the accepted markers of statutory interpretation, which are similarly relevant to judicial review regarding questions of law: text, context, and purpose.

${ }^{46}$ Dunsmuir, supra note 3 at para 27.

${ }^{47}$ As noted by Rothstein $\mathrm{J}$ in Khosa, supra note 44 at para 77: "the creation of an administrative decisionmaker did not by itself give rise to a tension with the supervisory role of the courts." This problem does arise in the context of privative clauses, where there is a statutory indicator that purports to oust the jurisdiction of the courts from review. Here, there is a real tension between the policing function and parliamentary intent. While I explicitly do not explore this point here, there is a fair argument as to whether privative clauses are constitutional in light of the policing function.
} 
precludes the decision under review. ${ }^{48}$ This means that the court must simply conduct an analysis of the statute to determine whether in text, context, and purpose, the decisionmaker (1) has a high degree of deference (e.g., if the decision-maker is interpreting the term "public interest" in the statutory context) and (2) the decision falls within the scope of the delegated authority.

The doctrine promulgated in Dunsmuir, resting on this false tension, created distortions in the policing function by imposing a standard of review analysis where none was required. For example, the court regarded cases where courts believed that a decisionmaker had expertise as engaging a tension between rule of law and legislative supremacy. Expertise, as noted below, was one of the factors that triggered the imposition of a "reasonableness" standard in Dunsmuir. The court created a framework that applied deference based on expertise in cases where it was not represented in statutory language. The same goes for the category of "jurisdictional questions," where courts created a category of easily-manipulable questions that counsel de novo review in cases where the statutory language may indicate deference. The result of these categories is the potential imposition of a more or less stringent intensity of review than the one indicated by the legislature. This raises obvious rule of law distortions because courts are no longer applying the law as set by the legislature but rather a law of its own creation.

There are several criticisms of this position that could be advanced. First, a focus on statutory language may seem to some as an unfortunate return to a pre-Dunsmuir, or even pre-CUPE ${ }^{49}$ state of affairs. Some may argue that courts no longer have a monopoly on legal determinations - that decision-makers participate in the making and interpretation of law, and concomitantly, that there is no "real" answer to the question of standard of review; statutory language may yield multiple results.

All of this can be seen as true, but none of it is a real criticism to the policing function. Statutory language can indeed be "open-textured,"50 and it is the role of the courts under the policing function to say so and apply that range of deference to a decision-maker. The role of the courts in having the last word on this range does not mean that administrative decision-makers' views are irrelevant. The function simply provides that while administrative interpretations of law should be regarded as legal, they must be double-checked by a court on judicial review. ${ }^{51}$ In other words, administrative

\footnotetext{
${ }^{48}$ Lorne Sossin, "Access to Administrative Justice and Other Worries" in Colleen M Flood \& Lorne Sossin, eds, Administrative Law in Context (Toronto: Emond Montgomery, 2013) 211 at 214.

${ }^{49}$ CUPE v NB Liquor Corporation, [1979] 2 SCR 227 [CUPE].

${ }^{50}$ For the classic statement, see HLA Hart, The Concept of Law (Oxford: Clarendon Press, 1961). For the application in the administrative law context, see H Wade MacLauchlan, "Judicial Review of Administrative Interpretations of Law: How Much Formalism Can We Reasonably Bear?” (1986) 36:4 UTLJ 343 at 352 [MacLauchlan]. ${ }^{51}$ See Canada $(A G)$ v Mossop, [1993] 1 SCR 554, La Forest J ("[i]n absence of other provisions indicating a disposition to limit judicial review, the normal supervisory role of the courts remains. The
} 
interpretations of law are legitimate, but can never be final because of the availability of judicial review and the policing function. ${ }^{52}$ This is parallel to the idea in Crevier that legislatures cannot fully immunize decisions from review. ${ }^{53}$

Second, some may argue that the focus on the "breadth" or "narrowness" of legislative language undermines deference and imposes legalistic tools of interpretation on decision-makers. ${ }^{54}$ The use of the tools of statutory interpretation, according to critics like Daly, could imperil the legal order by allowing administrative decisions to stand simply because they fall into some court-constructed "reasonable range" while being inconsistent with fundamental values of the legal order.

Although this is an important criticism, it misses the point. First, one cannot escape the role of statutory interpretation in administrative law. The Supreme Court has rightly noted that judicial review is simply a function of statutory interpretation ${ }^{55}$ because decision-makers are empowered by statute. ${ }^{56}$ The tools of statutory interpretation, if applied authentically, are the best measurements the courts have developed to determine whether a decision accords with the enabling statute. These tools are not inherently inconsistent with fundamental values of the legal system because they do not narrowly focus on a statute's textual meaning. Instead, the modern approach to statutory interpretation also focuses on the purpose of the statute and the broader context of the statute-book - connections to the broader legal universe. In short, if the tools of statutory interpretation are not used, how should courts determine whether a decision is legal?

Second, determining the options available to a decision-maker does not necessarily undermine deference. Daly asserts that the tools of statutory interpretation harken back to the days of ultra vires by differentiating between "clear" and "unclear" statutory provisions. According to Daly, the problem with this argument is the faulty distinction; there is no way to distinguish between "clear" and "unclear" statutory provisions, and there is no reason to assume that the legislature only delegated authority

administrative tribunal, of course, is authorized to make determinations on these questions, but they are not to be insulated from the general supervisory role of the courts" at 584).

52 Even David Dyzenhaus, one of the leading proponents of deference, accepts this proposition: see Dyzenhaus, "Constituting," supra note 19 at 456.

${ }^{53}$ Crevier, supra note 14 at 236.

54 Paul Daly, "Unreasonable Interpretations of Law" in Joseph Robertson, Peter Gall, \& Paul Daly, eds, Judicial Deference to Administrative Tribunals in Canada (Markham: LexisNexis, 2014) at 235-36 [Daly]. See also Frank AV Falzon, "Statutory Interpretation, Deference and the Ambiguous Concept of ‘Ambiguity' on Judicial Review” (2016) 29 Can J Admin L \& Prac 135.

${ }^{55}$ Bibeault, supra note 14 at para 120. Contrast this with the Supreme Court's statement in Barrie Public Utilities v Canadian Cable Television Assn, 2003 SCC 28 at para 86: "the broad policy context of a specialized agency infuses the exercises of statutory interpretation such that the application of the enabling statute is no longer a matter of "pure statutory interpretation." I proceed on the assumption that this comment has not ousted the courts' comments in later cases, which implicitly and explicitly hold that courts must apply the ordinary tools of statutory interpretation when characterizing administrative interpretations of law.

${ }^{56}$ Dunsmuir, supra note 3 at para 29. 
to a decision-maker for only "unclear" statutory provisions. According to critics like Daly, "ambiguity" is thus an unprincipled gateway to deference.

The policing function has never been about ambiguity or clarity but instead about whether a particular legislative term is or is not open-textured. This is a fine but important distinction. An open-textured term is not an ambiguous term-it is simply a term that could clearly (rather than ambiguously) mean many different things, as opposed to an ambiguous term where the meaning is unclear. The term "public interest," for example, is not ambiguous. There are many meanings associated with the term that may make sense within a statutory context, but those meanings are not necessarily unclear. In such a case, as opposed to a case of ambiguity, deference to the decision-maker is warranted. On the other hand, a closed-textured term is not necessarily ambiguous or unambiguous, but it provides fewer options to a decision-maker. An example might be where the legislature provides a "statutory recipe" that must be followed in specific cases. ${ }^{57}$ There is likely little room in such a case for a decision-maker to adopt any interpretation outside the recipe. At the most extreme end, there may be only one interpretation available to the decision-maker, ${ }^{58}$ even if such situations are exceedingly rare. ${ }^{59}$ But in these cases, the "statutory recipe" may not be ambiguous at all because the options available to the decision-maker are clear.

Under the policing function, ambiguity is not the gateway for deference. The policing function, which is rooted in the idea that courts must discover and impose the legislature's meaning ${ }^{60}$ on statutory delegates, must pay attention to the relative contingency of statutory language in its purposive context. It must give effect to this language in order to respect the boundaries set by the legislature. The authentic application ${ }^{61}$ of the tools of statutory interpretation does not undermine deference because deference is only a function of the very language that courts must interpret. The relative deference that might accrue to a decision-maker, on the spectrum based on open or closed textured language, is what a court on judicial review must determine. This puts the onus on the legislature to mandate deference if it sees fit.

Finally, one may wonder why the policing function should not be concerned with so-called "external criteria," that is, criteria unrepresented in statute. The answer goes back to the fundamental basis of the administrative state, namely, its genesis in statute.

\footnotetext{
${ }^{57}$ See Canada (Minister of Transport, Infrastructure and Communities) v Jagjit Singh Farwaha, 2014 FCA 56 at para 91 [Farwaha].

${ }^{58}$ McLean v British Columbia (Securities Commission), 2013 SCC 67 at para 38.

${ }^{59}$ MacLauchlan, supra note 50 at 354: "one would be hard-pressed to point to a text in Canadian administration which is so clear on its face ... that only one 'correct' interpretation, that being the one intended by the legislature, will be available."

${ }^{60}$ Richard A Posner, Reflections on Judging (Cambridge: Harvard University Press, 2013) at 215.

${ }^{61}$ As opposed to an inauthentic application of these tools designed to achieve a personal outcome of the judge: see Canada v Cheema, 2018 FCA 45 at para 80. See also Mark Mancini, "Statutory Interpretation From the Stratasphere: Recent Federal Court of Appeal Cases," Adv Q [forthcoming].
} 
Considerations that are not rooted in statute could point to an answer on the standard of review that undermines what the legislature has specified in statute. For example, if expertise is considered a reason for deference, but there is no indication of expertise rooted in statute (or the legislature has otherwise implicitly specified that deference is not owed to a particular decision-maker), a court could apply a deferential standard of review when the legislature impliedly indicated that it preferred a less deferential standard of review. The same is true of other outside criteria, such as the common belief that a decision that is truly important to a claimant means that a court should review that decision under a narrower reasonableness standard with a more limited range of reasonable outcomes. ${ }^{62}$ In that case, the legislature may speak in capacious terms about the decision-maker's ability to render a decision according to its own policy mandate, even despite the importance to the person affected. But, if a court views the importance of the decision as a deciding factor, it will impose a stringent standard of review when the legislature may have intended otherwise.

The guiding light of the standard of review analysis is the meaning of legislative language. Absent constitutional objection, that language binds. ${ }^{63}$ The myths distort the determination of this statutory range by creating categories of review that exist outside the statute. The categories are not related to a synthetic consideration of text, context, and purpose, but rather are rooted in different justifications for deference or de novo review. These categories impose different intensities of review that may belie the actual intensity of review implicit in the statute.

\section{MYTH 1: EXPERTISE WRIT LARGE IS A REASON FOR DEFERENCE}

The first myth of Canadian judicial review is the notion that a generalized idea of expertise not represented in statutory language justifies deference on questions of law. Indeed, expertise has been described by the Supreme Court as the strongest justification for deference. ${ }^{64}$ Despite this endorsement, expertise and its shortcomings have not been extensively explored as a reason for deference. ${ }^{65}$ Doctrinally and practically, "expertise" fails to satisfy as a reason for courts to look away from statutory text toward unproven qualifications on the part of administrative decision-makers. Expertise can only play a role if it is represented in statute and is consistent with the policing function.

\footnotetext{
${ }^{62}$ Farwaha, supra note 57 at para 91.

${ }^{63}$ I leave open the question of whether a legislative delegation can go too far-whether there is some element of a non-delegation doctrine in Canada or some constitutional problem with judicial deference. This is an unexplored area of Canadian administrative law. For more on this issue, see Lorne Neudorf, "Reassessing the Constitutional Foundation of Delegated Legislation in Canada," Dal LJ [forthcoming]. ${ }^{64}$ Canada (Director of Investigation and Research) v Southam Inc, [1997] 1 SCR 748 at para 50.

${ }^{65}$ Finn Makela, "Acquired Expertise of Administrative Tribunals and the Standard of Judicial Review: The Case of Grievance Arbitrators and Human Rights Law” (2014) 17 CLELJ 346 at 348 [Makela].
} 


\section{The Myth-Doctrinal Development}

Historically, the notion of expertise as a doctrinal and practical reason for deference can be divided into three periods: its introduction in CUPE, the pragmatic and functional era, and the Dunsmuir era. The so-called pragmatic and functional era took most seriously the idea that expertise is relative and not absolute and that it must be justified, not assumed. ${ }^{66}$ Now, however, expertise is used as a reason for deference when it does not exist and is not represented in statutory language. This is contrary to the policing function, which enforces statutory language and not abstract concepts of expertise.

CUPE was the first and most prominent case that relied on expertise as a reason for deference. In CUPE, the court accepted that expertise is a reason for legislatures to delegate authority to administrative decision-makers, ${ }^{67}$ particularly labour boards. While $C U P E$ introduced the concept of expertise as a reason for deference, the so-called pragmatic and functional era refined the idea and reduced its potency. This is surprising because mainstream literature generally attacks the pragmatic and functional era. ${ }^{68}$ But two examples demonstrate that, at least on the expertise question, the pragmatic and functional era was more consistent with the policing function.

In Pasiechnyk, ${ }^{69}$ the Supreme Court dealt with an appeal on a judicial review of a decision of the Saskatchewan Workers' Compensation Board that involved the question whether certain statutory actions were barred against the Government of Saskatchewan. The main issue was the standard of review for decisions of the Saskatchewan Workers' Compensation Board. In determining that exclusive authority was vested in the Board to make a final decision as to whether the action was statute-barred, the court reviewed the expertise of the Board, as represented in various statutory provisions. ${ }^{70}$ These provisions convinced the court that " $\mathrm{t}]$ he composition, tenure, and powers of the Board demonstrate that it has very considerable expertise in dealing with all aspects of the workers' compensation system." ${ }^{71}$ In other words, the court conducted an analysis of the statute. The court pointed to statutory proof of the expertise of the Board, indicating that the legislature intended to vest in it powers to decide the particular question of law at issue.

\footnotetext{
${ }^{66}$ Michel Bastarache, "Dunsmuir 10 Years Later" (9 March 2018), online (blog): Paul Daly: Administrative Law Matters <www.administrativelawmatters.com/blog/2018/03/09/dunsmuir-10-yearslater-hon-michel-bastarache-cc-qc>: "I might add that we did not say that expertise would be presumed, as some subsequent cases have held; in my opinion, deference had to be earned and justified in the context."

${ }^{67}$ CUPE, supra note 49 at $235-36$.

${ }^{68}$ See e.g. Dustin Kennall, "De-Regulating the Regulatory Compact: The Legacy of Dunsmuir and the Jurisdictional Question Doctrine (2011) 23 Can J Admin L \& Prac 115.

${ }^{69}$ Pasiechnyk v Saskatchewan (Workers' Compensation Board), [1997] 2 SCR 890 [Pasiechnyk].

${ }^{70} \mathrm{Ibid}$ at paras 37-38.

${ }^{71}$ Ibid at para 38.
} 
Pasiechnyk does not stand alone. In Pushpanathan, the notion of expertise was further defined at a theoretical level. First and foremost, the court characterized expertise as a relative concept in relation to the particular problem before the court. The court described this concept by noting:

Making an evaluation of relative expertise has three dimensions: the court must characterize the expertise of the tribunal in question; it must consider its own expertise relative to that of the tribunal; and it must identify the nature of the specific issue before the administrative decision-maker relative to this expertise. ${ }^{72}$

Based on this account of expertise and the particular question before the court, it must analyze whether the administrative decision-maker has expertise on a particular legal question; not in the abstract. This is a relatively high bar. If a specific question is legal, it asks a decision-maker to bring to bear specific legal knowledge, not generalized policy knowledge or subject-matter expertise.

In reading Pasiechnyk and Pushpanathan together, it becomes clear that expertise is a concept that (1) must be evaluated according to statutory indicators referring, for example, to "compensation, tenure, and powers"; (2) is in relation to a specific legal question before the judicial review court; and (3) is compared in relation to the expertise of the judicial review court. This definition of expertise is intimately woven with the policing function. The court will not abdicate the intensity of its review function unless there is some indication that the decision-maker possesses expertise on the precise legal question in issue - and that indication must appear in statute.

Pushpanathan is an example of this three-pronged definition of expertise. The question was the standard of review to be applied to decisions of the Immigration Board on refugee determinations. The majority of the court concluded that the matter was reviewable on a standard of correctness, in part because the Board enjoyed no relative expertise on international human rights law, which was the sort of expertise directly applicable in determining exclusion under the Convention. In evaluating expertise, the court pointed to statutory indicators, noting that "[o]nly 10 percent of the members of the Board are required to be lawyers ... and there is no requirement that there be a lawyer on every panel."73 As a result, it was "unthinkable"74 to the court that the definition of an international human rights guarantee could be left to the Board. The court concluded that the "factual expertise enjoyed by this administrative decision-maker does not aid it in the interpretation of this general legal principle." 75 In this sense, Pushpanathan is a direct

\footnotetext{
${ }^{72}$ Pushpanathan, supra note 43 at para 33.

${ }^{73}$ Ibid at para 47.

${ }^{74}$ Ibid.

${ }^{75}$ Ibid.
} 
application of the three-pronged approach to expertise. The precise question before the Board - the explication of the Convention - is identified by the court; the court's expertise is evaluated in relation to the Board's expertise on that precise question. In doing so, the court relates the expertise to statutory indicators (or lack thereof) in the Board's enabling statute.

Pezim provides another example of the Supreme Court evaluating expertise according to statutory indicators. ${ }^{76}$ In Pezim, the court recognized that deference could still be provided to decision-makers even in the absence of a privative clause and a full statutory right of appeal. Still, the court did not embrace a non-statutory concept of expertise. It considered expertise in the context of the decision under review, that being financial markets. ${ }^{77}$ It then pointed to statutory provisions that indicated expertise, in light of the highly discretionary language used by the legislature in framing the decisionmaker's authority. ${ }^{78}$ Even here, where expertise was the primary reason for deference, the court identified statutory indicators of expertise that related to the interpretive problem at hand.

These cases demonstrate that the pragmatic and functional era was a high point for a statutory explanation of expertise that could stand consistently with the policing function. However, in the post-Dunsmuir era, the notion of expertise has become unhinged from the enabling statute. In Khosa, Justice Rothstein wrote a concurring opinion that pointed out the problem with the idea of expertise as it had developed. He noted that "recognizing expertise as a free-standing basis for deference on questions that reviewing courts are normally considered to be expert on ... departs from the search for legislative intent." ${ }^{, 79}$ To Justice Rothstein, the enactment of a privative clause is indicative of a legislative intent to recognize expertise, but without more, expertise alone is not a reason for deference.

Justice Rothstein's concurrence has not been followed. A good example of the modern trend is Edmonton East. In that case, without evaluating the relative statutory expertise of the decision-maker as counselled in Pushpanathan, Justice Karakatsanis for the majority accepted the sweeping proposition that "expertise is something that inheres in a tribunal as an institution." ${ }^{80}$ While the Supreme Court accepted that expertise "may also arise where legislation requires that members of a given tribunal possess certain qualifications," it concluded that this was not a necessary condition. ${ }^{81}$ Thus, Edmonton East doubles down on a notion of expertise that is not rooted in statute.

\footnotetext{
${ }^{76}$ Pezim v British Columbia (Superintendent of Brokers), [1994] 2 SCR 557 [Pezim].

77 Ibid at 593.

${ }^{78}$ Ibid at 594.

${ }^{79}$ Khosa, supra note 44 at para 93.

${ }^{80}$ Edmonton East, supra note 13 at para 33.

81 Ibid.
} 
This brief history represents the extraordinary rise of a notion of expertise. In just over a decade, the court went from believing it "unthinkable" that an administrative decision-maker could pronounce on serious questions of law without expertise, to believing that such expertise inheres in the tribunal itself "as an institution." 82 The result of this jurisprudential shift is a powerful justification for deference that is not necessarily rooted in the enabling statute of the decision-maker.

\section{The Myth Explained}

As noted above, the myths are problematic because they may impose a different standard of review than the one that courts determine through the policing function. Expertise does so by counselling the application of deference when an analysis of the administrative decision-maker's enabling statute may say otherwise. Specifically, expertise is not a sound reason for a court to abnegate the policing function, for both doctrinal and practical reasons.

\section{Doctrinal Objections}

Doctrinally, expertise that is not represented in statute does not provide a convincing basis on which courts can defer. In the first place, "expertise" does not speak to any obligation on the part of courts to ignore the statutory boundaries that cabin the discretion of a decision-maker. Second, the independence of the courts when conducting the policing function is put into question if the government enjoys deference in judicial review matters, based on its own statutory creations.

Even if a decision-maker has perfectly equivalent relative expertise to a court on a particular legal matter, the court, not the administrative decision-maker, is duty bound to enforce statutory boundaries. From a strictly doctrinal perspective, it does not matter that administrative decision-makers are experts because they have no legal or constitutional authority to police their own statutory boundaries. On this note, Justice Scalia put the problem well:

[Expertise is] a good practical reason for accepting the agency's views, but hardly a valid theoretical reason for doing so. If I had been sitting on the Supreme Court when Learned Hand was still alive, it would similarly have been, as a practical matter, desirable for me to accept his views in all of his cases under review, on the basis that he is a lot wiser than I, and more likely to get it right. But that would

\footnotetext{
${ }^{82}$ Ibid.
} 
hardly have been theoretically valid. Even if Hand would have been de facto superior, I would have been ex officio so. ${ }^{83}$

If it is true, as the Supreme Court has accepted, the courts must "engage in surveillance of lower tribunals" to vindicate the rule of law, ${ }^{84}$ then it follows that mere subject matter expertise cannot oust that power or authority. If the courts do not exercise independent judgment to determine the standard of review, they do not fulfill their constitutional duty, regardless of the expertise of a decision-maker.

This proposition can be demonstrated through an example involving two tribunals. Say one tribunal is supposedly "expert" in the abstract, but its legislative language significantly constrains its decision-making power-perhaps it specifies a list of criteria that must be considered, following which a claimant's case is accepted. In this case, assume there is no statutory indicator of expertise. For a reviewing court applying the policing function, the decision-maker would have a limited range of reasonable options available, even if it could be considered "expert" in the abstract.. On the other hand, another tribunal may be profoundly inexpert, but it may also be empowered to act in the "public interest." All things being equal, this decision-maker may have more reasonable options available. . In these cases, the policing function warrants deference to the latter decision-maker, but not the former decision-maker, even despite its expertise. This is because no matter whether the decision-maker is expert or not, the policing function must be independently exercised with a view to the statutory boundaries of the decision-maker. Those statutory boundaries could have been created for any number of reasons, which do not necessarily include the expertise of the decision-maker.

Similarly, deference based on expertise undermines a key implicit component of the policing function: its independence. The rule of law is intimately connected to an independent judiciary. Specifically, the rule of law requires a judiciary that is separate and apart from the parties before it. In Tennant, Justice Stratas explained this concept, noting that "there must be an umpire who can meaningfully assess whether the law has been obeyed and grant appropriate relief. ... [B]oth the umpire and the assessment must be fully independent from the body being reviewed." 85 On this account, looking to unwarranted expertise is at best a distraction from the dispassionate review that courts must undertake and, at worst, doctrinal bias in favour of the government, a party to some judicial review. ${ }^{86}$ When the judiciary applies doctrines of deference based on expertise,

\footnotetext{
${ }^{83}$ Antonin Scalia, "Judicial Deference to Administrative Interpretations of Law" (1989) 3 Duke LJ 511 at 514.

${ }^{84}$ Wall, supra note 13 at para 13.

${ }^{85}$ Canada (Citizenship and Immigration) v Tennant, 2018 FCA 132 at para 23; see also para 24 [Tennant].

${ }^{86}$ Philip Hamburger, The Administrative Threat (New York: Encounter Books, 2017) at 46 [Hamburger]. This has obvious relevance in cases that are particularly fundamental to personal freedoms and liberties, including immigration and citizenship cases.
} 
it accepts that the decision under review is owed special respect because of the expertise of the decision-maker. Accordingly, when the government comes to court to argue for the legality of the decision, it enjoys a presumption that assists its arguments. The party challenging the decision must rebut this presumption to allow the court to exercise de novo review in an independent way.. The imposition of evidentiary and legal presumptions changes the task of courts on judicial review. Instead of determining the degree of deference owed to a decision-maker based on statutory indicators (that may include indications of expertise, such as in Pasiechnyk), the court determines whether there is legal warrant to rebut the presumption. But fundamentally, this presumption assists the government, impacting the independence of the court and imposing a burden on a challenger.

These doctrinal problems are rooted in institutional considerations. Expertise that is not represented in statute changes the task of courts on judicial review, which is constitutionally guaranteed, and asks courts to conduct independent review. The erosion of institutional capacities is reason enough to question expertise as a reason for deference.

\section{Practical Objections}

Putting aside any doctrinal objections, expertise is also marshalled as a practical justification for deference and a reason why legislatures delegate to decision-makers in the first place. But even on these counts, expertise fails to satisfy because it often lacks empirical proof. That is, courts assume that it exists in absence of evidence to the contrary. The onus is on those seeking to justify expertise as a reason for deference to satisfy the court that it should limit its policing function in view of the decision-maker's expertise. ${ }^{87}$

Professor Daly notes that practical justifications for deference "are variable in nature and should be taken into account by reviewing courts, if an interpretation of the statutory language suggests that the practical justifications motivated the delegation of power." ${ }^{88}$ This imposes some requirement of empiricism: ${ }^{89}$ expertise must exist, or at least be a valid reason why a delegation would even occur, implying its existence. Otherwise, courts are asked to engage in "legislative mind-reading" in an attempt to find reasons that may not exist for legislative delegation. ${ }^{90}$ In practice, this means that a court should clearly identify in its decision whether the decision-maker has specific expertise bearing on the legal problem.

\footnotetext{
${ }^{87}$ Ibid.

${ }^{88}$ Paul Daly, A Theory of Deference in Administrative Law: Foundations, Application and Scope (Cambridge: Cambridge University Press, 2012) at 5 (emphasis added).

${ }^{89}$ See RE Hawkins, "Reputational Review I: Expertise, Bias and Delay" (1998) 21:1 Dal LJ 5 at 12-13;

Hamburger, supra note 86 at 47.

90 Lisa Schulz Bressman, “Chevron’s Mistake” (2009) 58:4 Duke LJ 549 at 576.
} 
However, in recent years, the Supreme Court does not actually engage in any analysis of the expertise of the decision-maker when it conducts judicial review. Instead, the court relies on the device of a presumption of deference, which applies whenever a decision-maker interprets its home statute or closely related statutes. The presumption is principally supported by 'the legislature's choice to give a specialized tribunal responsibility for administering the statutory provisions, and the expertise of the tribunal in so doing." "91 Because "those working day to day in the implementation of frequently complex administrative schemes have or will develop a considerable degree of expertise or field sensitivity," 92 the presumption reflects the reality as the court sees it.

On this account, the presumption of deference based on expertise does no harm, and in fact simplifies judicial review. The presumption saves courts the time and costs associated with conducting review of a decision-maker's expertise in every single case, especially if the decision-maker accumulates expertise over time because of its "field sensitivity." "93 If it is true in every case (or even in most cases) that legislatures delegate authority to a decision-maker because of their expertise, then a presumption avoids a lengthy standard of review analysis. This would be consistent with Dunsmuir's direction that a standard of review analysis is not required in every case. ${ }^{94}$

But, again, the existence of a practical justification for deference is connected to the idea that expertise must actually exist. This requires a consideration of the kind of expertise that courts should consider when determining whether a decision-maker is "expert." On the one hand, the Supreme Court has spoken about both "institutional" and "personal" expertise. ${ }^{95}$ These forms of expertise may overlap because the decision-maker may have appointment procedures to ensure institutional competence. ${ }^{96}$ But as Justice Rothstein pointed out in Khosa, one cannot easily transfer such policy expertise over to the legal context because there is no necessary empirical link between these two types of knowledge. In fact, a decision-maker with subject-matter expertise "will tend to overestimate the importance of that area and underestimate the significance of others."97 This would be undesirable in a statutory interpretation context where, in the modern era, administrative decision-makers and the courts share responsibility for interpreting and applying law. ${ }^{98} \mathrm{~A}$ narrow focus based on the expertise of the decision-maker risks

\footnotetext{
${ }^{91}$ Edmonton East, supra note 13 at para 33.

${ }^{2}$ Ibid, citing DJ Mullan, "Establishing the Standard of Review: The Struggle for Complexity?" (2004)

17 CJALP 59 at 93.

93 See Andrew Green, "Can There Be Too Much Context in Administrative Law? Setting the Standard of Review in Administrative Law” (2014) 47:2 UBC L Rev 443.

${ }^{94}$ Dunsmuir, supra note 3 at para 57.

${ }^{95}$ Nor-Man Regional Health Authority Inc v Manitoba Association of Health Care Professionals, 2011 SCC 59 at para 53.

96 Makela, supra note 65 at 350.

${ }^{97}$ Hamburger, supra note 86 at para 60.

${ }^{98}$ See Kevin M Stack, “Overcoming Dicey in Administrative Law” (2018) 68:2 UTLJ 293.
} 
devaluing the idea of statutory interpretation as a purposive exercise that connects the statute to superseding legal values and norms.

Once the proper sort of expertise has been identified, and because courts must always determine the standard of review de novo on judicial review, ${ }^{99}$ they must examine whether this expertise exists in fact. If expertise does not exist, or there is no evidence of expertise, then courts have no warrant to defer because the legislature may not have created the decision-maker based on expertise. If courts do not even attempt to ascertain expertise, there is no sound reason to assume it. In absence of any empirical evidence (either because the evidence does not exist or because courts do not seek it out) the presumption has the potential effect of presuming the untrue. Deference could apply in more cases than it otherwise would.

This is entirely predictable. The presumption of home-statute interpretation can be characterized as an overbroad "rule" as opposed to a "standard," because it defines the context of the law ex ante. ${ }^{100}$ That is, on the happening of the triggering event (interpretation of home statute by a decision-maker), deference automatically applies and is not easily rebutted. Rules, which have many benefits including the saving of costs associated with case-by-case adjudication, ${ }^{101}$ suffer from the fatal flaws of overbreadth and underbreadth. ${ }^{102}$ Because the presumption exists without an investigation into expertise, it suffers principally from overbreadth. The Supreme Court's own description of overbreadth regarding section 7 of the Charter of Rights and Freedoms is helpful in this context: a law that captures conduct not covered by its underlying purpose. ${ }^{103}$ In administrative law, the presumption captures some conduct that bears no relation to its underlying purpose because the presumption applies deference in areas where its underlying justification - expertise - may not exist.

The overbreadth could be limited if the Supreme Court routinely looked to other factors to rebut the presumption. For example, in Rogers Communications, the majority of the court held that in a case where a decision-maker and a court had concurrent jurisdiction, "it must be inferred that the legislative intent was not to recognize superior expertise of the Board relative to the court with respect to such legal questions." 104 This is a good example of the court looking to other statutory indications to rebut the courtcreated presumption of deference based on expertise. But this is not a regular occurrence. Most recently, the Supreme Court noted that an approach looking to contextual legislative

\footnotetext{
${ }^{99}$ Celgene Corp v Canada (AG), 2011 SCC 1 at para 33.

${ }^{100}$ Cass R Sunstein, "Problems With Rules" (1995) 83:4 Cal L Rev 953 at 961 [Sunstein].

${ }^{101}$ This is a simplistic description of the relevant trade-offs between rules and standards. For the classic article on the matter, see Louis Kaplow, "Rules Versus Standards: An Economic Analysis" (1992) 42:3 Duke LJ 557 at 568.

${ }^{102}$ Sunstein, supra note 100 at $990-91$.

${ }^{103}$ Carter v Canada (AG), 2015 SCC 5 at para 85.

${ }^{104}$ Rogers Communications Inc v Society of Composers, Authors and Music Publishers of Canada, 2012 SCC 35 at para 15.
} 
factors "should be applied sparingly." 105 This suggests that the presumption of deference could apply without the court looking to legislative factors that could demonstrate the actual standard of review impliedly set by the legislature. This reverses the hierarchy of laws; the standard of review as determined by the tools of statutory interpretation takes precedence over the Court's own common law presumption. The result is a self-applying presumption of deference supported by expertise that may not actually exist.

The presumption of deference short-circuits the policing function by essentially fettering it. In the case of a presumption, it is a court-created device used to simplify the selection of the standard of review. It is not law set out by the legislature. Yet the court binds its selection of the standard of review to this device without an investigation of legislative signals otherwise. In this sense, the analogy of fettering is descriptive of what the court does with the question of expertise. Without investigating statutory signals, the court relies on its own doctrinal creation rather than the legislature's creation.

From the perspective of the policing function, this status quo is undesirable. If the Supreme Court does not routinely investigate legislative signals to determine whether the presumption is rebutted, more leeway could be given to administrative decision-makers than they otherwise would have on an objective analysis of the statute. This is clearly contradictory to the point of the standard of review analysis, which is, namely, to determine legislative intent. The systemic effects of such a rule should not be understated. When a court defers when it should not, it is undermining its constitutional role as defined by the principles of legislative supremacy and the rule of law.

\section{The Way Forward}

What is the solution if the presumption is unjustified? There are three potential options that would bring the doctrine away from the myth of expertise and toward the policing function. The first solution is for a court to demand proof of expertise-in-fact. It could, through affidavit evidence or otherwise, demand that a party arguing for deference prove as a fact the practical expertise of decision-makers (on an institutional or individual level) on the legal matter in question. However, this presents obvious problems. It runs counter to the basic idea of a presumption of home statute interpretation in the first place; absent rebutting facts, the presumption saves the court transaction costs of determining the standard of review in every case. It is further unclear how, procedurally, this would work in the context of a judicial review hearing that is summary in nature and not singularly focused on the standard of review. ${ }^{106}$ Further, to the extent that the standard of review is simply a function of legislative intent, a resource-heavy investigation into

${ }^{105}$ Canada (Canadian Human Rights Commission) v Canada (AG), 2018 SCC 31 at para 46 [CHRC].

${ }^{106}$ Lessard-Gauvin v Canada (AG), 2016 FCA 172 at para 8. 
expertise is, arguably, the problem with today's standard of review analysis. Proving expertise as a fact could further distract courts from the merits of a case. ${ }^{107}$

A second option is to retain the presumption of reasonableness, based on expertise, but to conduct a statutory analysis in specific cases to determine whether the legislature intended to specify a different standard of review. As noted above, the presumption is not per se problematic if there is still a role for the constitutionally prescribed policing function. Even assuming this is true, one should ask why anything should be presumed in the law of judicial review. Expertise does not necessarily inhere in every decision-maker such that a presumption makes sense, even on an institutional level. If a court is to conduct the policing function in every case, the presumption adds nothing to the analysis.

A third option is to determine whether statutory indicators of expertise exist. It is possible for the legislature to delegate decision-making powers to a decision-maker for reasons other than its expertise. ${ }^{108}$ Accordingly, if expertise is to be a justification for deference, courts should look to institutional and individual statutory indicators of expertise to determine whether there is any legislative intent for the court to recognize the decision-maker's expertise. This framework would operate alongside the court's analysis of the statutory language, determining whether - in text, context, and purposea particular decision accords with the legislation. In these circumstances, expertise could serve to expand the range of reasonable outcomes available to a decision-maker. This is an application of the ordinary tools of statutory interpretation, recognizing the Supreme Court's comment that judicial review is merely a function of statutory interpretation. ${ }^{109}$

Under this formulation, the three-step framework set out by the court in Pushpanathan and Pasiechnyk describes the relevant sort of expertise. Expertise must be (1) proven in statute; (2) relevant to the precise issue before the court; and (3) greater than the court's expertise on the precise issue. Unsubstantiated expertise, or assumed expertise, has no doctrinal role in judicial review. Further, expertise that does not bear on the legal issue before the court-for example, technical policy expertise that does not directly impact the decisive question before the court - should not figure into the balance. This sort of expertise, for the reasons noted above, is not relevant to the court conducting the policing function on judicial review.

This latter option - the court seeking statutory signals - is most consistent with the policing function. Without statutory indicators, the expertise justification is only an "epistemic" reason for deference; it is a reason for courts to defer based on the knowledge of a decision-maker. ${ }^{110}$ This form of deference can be analogized to so-called Skidmore

\footnotetext{
107 Wilson v Atomic Energy of Canada Ltd, 2016 SCC 29 at para 25.

${ }^{108}$ Makela, supra note 65 at 356.

${ }^{109}$ Bibeault, supra note 14 at para 120.

${ }^{110}$ Paul Horwitz, "Three Faces of Deference" (2008) 83:3 Notre Dame L Rev 1061 at 1085.
} 
deference in the United States, where a decision-maker has the power to persuade "if lacking power to control." "111 The relative expertise of the decision-maker is a reason for a court to give persuasive weight to a decision, but this is distinct from a legal reason for deference that is rooted in the separation of powers or on the grounds that the legislature vested powers in a decision-maker. ${ }^{112}$ From the perspective of the policing function, the epistemic reason for deference does not justify a court providing deference because it does not indicate an intention on the part of the legislature to mandate deference.

However, once manifested in legislative language, the epistemic reason for deference transforms into a legal one that binds the court (absent constitutional objection). In such a case, the legislature has indicated that it created the decision-maker with certain particular expertise in a matter. Accordingly, in these situations, there are good legal reasons to defer. This is part of the text and context that either expands or narrows the range of reasonable outcomes available to the decision-maker. Where legislative language is present, courts must give effect to it. Therefore, there is a clear distinction between expertise unrepresented in statute and expertise appearing in statute. The latter is a clear legislative intention to which courts should give effect and the former is not.

\section{MYTH 2: JURISDICTIONAL QUESTIONS EXIST}

The concept of jurisdictional questions has played a typical "trickster" role in Canadian administrative law. Jurisdictional questions were identified by courts as issues over which courts had exclusive authority to opine. Decision-makers were owed no deference on these questions, whereas on other questions, deference was possible. Therefore, there was a clear analytical distinction drawn by judicial review courts based on different categories of questions.

Nominally, this analytical division continues in modern day Canadian administrative law. A vocal minority of the Supreme Court believes that jurisdictional questions still exist. This minority insists on the analytical distinction between jurisdictional errors and all other errors of law, arguing that it is required by the rule of law. Yet, as noted by the Supreme Court itself, not one jurisdictional question has been identified before the Supreme Court post-Dunsmuir. ${ }^{113}$

In view of the policing function, there is little reason to hold onto the analytical distinction between these errors of law and continue to support the myth of jurisdictional questions. In fact, the analytical distinction only matters for the determination of standard of review, a court-created construct. The typical formulation holds that a "jurisdictional question" is simply descriptive for a type of question that courts should review for correctness. But on the basis of fundamental principle, the standard of review categories

111 Skidmore v Swift \& Co, 323 US 134 at 139 (1944).

112 Ibid.

${ }^{113}$ CHRC, supra note 105 at paras 35-37. 
are unnecessary, and jurisdictional errors are simply errors in appreciation of statutory boundaries like all administrative law errors. Whether this is framed as a "jurisdictional question" or something else is merely descriptive and doctrinally irrelevant.

\section{The Myth-Doctrinal Development}

In practice, it is, and always has been, incredibly difficult to draw a distinction between legal errors and jurisdictional errors. ${ }^{114}$ Yet the history of jurisdictional error is characterized by this tension. Fundamentally, it is a debate about whether the rule of law requires a particular category of question that invites "correctness" review.

Historically, jurisdictional problems were framed as "entry" or "preliminary" questions ${ }^{115}$ that the decision-maker had to get right: did the decision-maker have jurisdiction over the dispute at hand? However, in CUPE, the Supreme Court criticized judges who characterized "as jurisdictional, and therefore subject to broader curial review, that which may be doubtfully so." ${ }^{116}$ While CUPE is considered by many to be the birth of a modern doctrine of deference, it did not kill jurisdiction. Instead, it kept the idea of jurisdiction for certain questions that were truly "jurisdictional" in nature, namely, matters that went to the ability of a decision-maker to hear and decide a case in the first place. Otherwise, courts were owed a significant margin of deference on matters relating to the legal merits. In this respect, $C U P E$ can be seen as merely a change in judicial attitude toward certain questions of law rather than a substantive change in doctrine. Courts, on the instruction of CUPE, were not supposed to overextend their role by framing as jurisdictional questions that went to the merits of a matter.

This distinction, however, did not mean that substantially different analyses applied to the determination of different categories of questions. To the Supreme Court, both sorts of errors caused a decision-maker to lose jurisdiction. The labels of jurisdictional and non-jurisdictional were most relevant as descriptive tools for the different standards of review to be applied on each question. However, both sorts of errors caused the decision-maker to commit a legal error, ${ }^{117}$ which in the court's verbiage, was a "loss of jurisdiction." 118 In Bibeault, the court's introduction of a "pragmatic and functional analysis," which focused on a number of factors relevant to the powers of the decision-maker, applied both to the determination of a decision-maker's jurisdiction strictly speaking (defined as "the power to decide") and to other regular errors of law. ${ }^{119}$

\footnotetext{
${ }^{114}$ CUPE, supra note 49 at 233.

115 See Halifax (Regional Municipality) v Nova Scotia (Human Rights Commission), 2012 SCC 10 at para 34, in which the court held that the "preliminary question" doctrine should no longer be followed. Such "preliminary questions" are now reviewable on a more deferential standard.

116 CUPE, supra note 49 at 233.

${ }^{117}$ Bibeault, supra note 14 at para 116.

118 Ibid at para 122.

${ }^{119} \mathrm{Ibid}$ at paras 122-27.
} 
In other words, the court drew a connection between jurisdictional errors and nonjurisdictional errors; each caused an error of law.

While there was still a distinction between jurisdictional and non-jurisdictional questions from a standard of review perspective, Bibeault moved toward analytical unity between these questions. From an analytical perspective, the same analysis applied to the consideration of a clause purporting to limit jurisdiction, because the question was fundamentally about the statutory boundaries of the decision-maker. While different standards of review applied, the court viewed jurisdictional questions and nonjurisdictional questions as one and the same - both were legal questions about a statute's boundaries, amenable to scrutiny with the pragmatic and functional approach introduced in Bibeault.

Somewhere down the line, this analytical unison between ordinary and jurisdictional errors of law was separated. Turning aside the old pragmatic and functional approach, Dunsmuir noted that courts must have "the final say on the jurisdictional limits of a tribunal's authority." 120 Accordingly, the Dunsmuir court reiterated its commitment to correctness review for "true questions of jurisdiction or vires." 121 Jurisdiction was properly described in "the narrow sense of whether or not the tribunal had the authority to make the inquiry." 122 In this sense, Dunsmuir quartered off jurisdictional errors as a separate error from other errors of law that could arise when a decision-maker interprets its home statute. The same tools of deference review-looking to the whole of the statute to determine the breadth of authority granted to the decision-maker-would not apply to the analysis of a clause purporting to limit a decision-maker's jurisdiction.

In Alberta Teachers, the Supreme Court arguably resiled from Dunsmuir and moved toward a merger of jurisdictional questions with all other errors of law. The court noted the confusion caused by the retention of this category of questions in Dunsmuir, ${ }^{123}$ and reasoned that "[ $\mathrm{t}]$ rue questions of jurisdiction are narrow and will be exceptional."124 The court also recognized the interaction between questions of true jurisdiction and other errors of law by noting that "[i]n one sense, anything a tribunal does that involves the interpretation of its home statute involves the determination of whether it has the authority or jurisdiction to do what is being challenged on judicial review," 125 confirming comments made in the previous Nolan case. ${ }^{126}$

\footnotetext{
${ }^{120}$ Dunsmuir, supra note 3 at para 30.

${ }^{121} \mathrm{Ibid}$ at para 59.

${ }^{122}$ Ibid.

${ }^{123}$ Alberta (Information and Privacy Commissioner) v Alberta Teachers' Association, 2011 SCC 61 at para 39 [Alberta Teachers].

${ }^{124}$ Ibid.

${ }^{125} \mathrm{Ibid}$ at para 34.

${ }^{126}$ Nolan v Kerry (Canada) Inc, 2009 SCC 39 [Nolan], Rothstein J (“[a]dministrative tribunals are creatures of statute and questions that arise over a tribunal's authority that engage the interpretation of a tribunal's constating statute might in one sense be characterized as jurisdictional" at para 33).
} 
The statement in Alberta Teachers is consistent with the policing function and the steps taken toward an analytical merge in Bibeault. The comment that all interactions of a tribunal of an administrative decision-maker with a home statute involve a question of whether the decision-maker has certain powers (jurisdiction broadly construed) is perfectly consistent with the comments in Bibeault. Yet, despite this admonition in Alberta Teachers, confusion persists.

Most recently, the Supreme Court had occasion to deal with two cases involving jurisdictional questions: Guerin ${ }^{127}$ and the $C H R C$ case. ${ }^{128}$ In Guerin, the issue in question was an arbitrator's legislative capacity to determine standing and whether a dispute was arbitrable. The court held that applying the reasonableness standard "undermines neither the rule of law nor the other constitutional bases of judicial review." ${ }^{129}$ On the other hand, the application of the correctness standard undermined the presumption of reasonableness on home statute interpretation. ${ }^{130}$ The court extended this argument in $C H R C$. It reasoned that courts should not retreat to a pre-Dunsmuir notion of jurisdiction. This is because "[w] here decision makers interpret and apply their home statutes, they inevitably determine the scope of their statutory power,"131 seconding comments in Alberta Teachers. The court indicated that "[o]ur jurisprudence has held that the constitutional guarantee of judicial review is premised on the courts' duty to ensure that public authorities do not overreach their lawful powers." 132 In addition, a focus on so-called "jurisdictional questions" tempts litigants and judges alike to return to correctness review.

Dissents in Guerin and CHRC attack this position. In Guerin, Justices Brown and Rowe pointed to what they called a "Gordian knot," which they described as the fact "that an administrative tribunal's jurisdiction ... is established and confined by its enabling ... statute."133 The Guerin dissenters nonetheless insisted on a distinction between jurisdictional errors and other errors, because as a matter of constitutional law, a decisionmaker must be correct on issues of jurisdiction. In $C H R C$, Justice Brown similarly dissented. He wrote that the majority's concerns about jurisdictional questions ignored the principle, endorsed in Dunsmuir, that the category is "fundamental to judicial review." 134 This is because "[t]he exercise of public power, including delegated public power, must always be authorized by law,"135 based on the rule of law.

The debate over jurisdictional questions is symbolized in the disagreement in the above cases. On the one hand, a vocal group maintains that the identification of

\footnotetext{
${ }^{127}$ Quebec (AG) v Guérin, 2017 SCC 42 [Guerin].

${ }^{128}$ CHRC, supra note 105.

${ }^{129}$ Guerin, supra note 127 at para 34.

${ }^{130}$ Ibid.

${ }^{131}$ CHRC, supra note 105 at para 38.

${ }^{132}$ Ibid at para 40.

${ }^{133}$ Guerin, supra note 127 at para 68.

${ }^{134}$ CHRC, supra note 105 at para 110.

135 Ibid at para 111.
} 
jurisdictional questions is important to determining the standard of review because it could invite correctness review. This position was advanced most forcefully by dissents in Guerin and CHRC. On the other hand, there is another line of cases-Bibeault, Nolan, Alberta Teachers, and the majority in $\mathrm{CHRC}$ - that moves toward analytical unison in jurisdictional and non-jurisdictional cases and reasons essentially that courts always determine their "jurisdiction" when interpreting their home statutes. As I will explain, this latter line of cases is most consistent with the policing function, which views jurisdictional questions as myths.

\section{The Myth Explained}

The concept of the "jurisdictional question" in Canadian administrative law is tortured. ${ }^{136}$ Part of this is a terminological problem. At various times, courts have used the term "jurisdictional error" 1) to describe any legal error committed by a decisionmaker; 2) in a limited manner, as a label for whether the court has the power to hear and decide a matter; and 3) as a category for a certain class of questions. The label causes analytical problems because, from the view of the policing function, all errors committed by a decision-maker are misapprehensions of the statutory grant given to the decisionmaker. Whether this is viewed as "jurisdiction" is unimportant and potentially impedes doctrinal progress. As such, the discussion proceeds on the basis that what is really at issue in judicial review is the statutory authority of a decision-maker granted by the legislature - that is, "what authority was intended to be given to the body in relation to the subject matter." 137

As such, a jurisdictional question simply means a question that goes to the statutory authority of a decision-maker, as do all other questions in administrative law. To be a helpful addition to the law of judicial review, the category of jurisdictional questions must serve some analytical purpose. The usefulness of jurisdiction begins to wane when even the Guerin dissenters admit that the notion of jurisdiction is simply a function of statutory boundaries.. If jurisdiction is conferred by statute, like all other administrative powers, what basis exists to treat such jurisdictional power any differently?

Instead, it is evident that the distinction between regular errors of law and jurisdictional questions persists because, and only because, of the "pillowfight" over standard of review. ${ }^{138}$ Regular errors of law draw review for reasonableness;

\footnotetext{
${ }^{136}$ As will be evident, my concern is not with the concept of "jurisdiction" per se; rather, it is with the specific concept of a "jurisdictional question." But to the extent that a court-informed version of jurisdiction creates this category, it is flawed.

${ }^{137}$ Dunsmuir, supra note 3 at para 29.

${ }^{138}$ Mark Mancini, "Not Just A Pillowfight: How the SCC Has Muddied the Standard of Review" (21 March 2017), online: Advocates for the Rule of Law <www.ruleoflaw.ca/not-just-a-pillowfight-how-thescc-has-muddied-the-standard-of-review>.
} 
jurisdictional questions, if they exist, invite review for correctness. Beyond this, the notion of jurisdiction is not determinative of a particular analysis. Rather, as the Supreme Court accepted in Pushpanathan, it is simply a descriptor for a particular standard of review and carries no real analytical weight. ${ }^{139}$ Similarly, the standards of review are simply judicial creations. They are categories (like the presumption of reasonableness) that assist a court on judicial review. However, because they are not matters of constitutional law, as is the policing function, they cannot be the grounding principles for the development of the law. We must start from first principles in examining why jurisdictional questions are a myth. ${ }^{140}$

Starting from the real premise of administrative law, its statutory basis, the policing function does not make any distinctions between standards of review. This is because the breadth of deference afforded to a particular decision-maker is a product of statutory interpretation. ${ }^{141}$ If there are no statutory signals indicating deference, then a court will conduct de novo review. As described above, this methodology is the core of the policing function and achieves a defensible balance between legislative supremacy and rule of law concerns. Courts enforce the boundaries agreed to by the legislature; that agreement is specified in legislative language. Where statutory indicators suggest a broad margin of appreciation, the court can show an appropriate amount of deference. When such a breadth is nowhere to be found in the language, then no deference should follow. ${ }^{142}$

When courts create arbitrary categories that invite correctness review, such as the jurisdictional questions category, they undermine the notion of deference. This is because a legislature may specify, in open-textured and deferential language, that a particular decision-maker has full authority to determine its jurisdiction, subject only to judicial review. In handling challenges to its jurisdiction, the decision-maker may have a wide margin of appreciation based on this language and has the opportunity to interpret its own statute. This is no different from any interpretation that a decision-maker will conduct in the general run of cases. This argument is well-stated by Justice Stratas in the recent Access Copyright case:

For the moment, let's define a so-called "jurisdictional question" as one requiring an assessment as to whether the administrator has done something that its legislation does not permit it to do. But to answer this question, we must interpret the legislation to define the limits of what the administrator can do. Thus, a

\footnotetext{
${ }^{139}$ Pushpanathan, supra note 43 at para 28.

${ }^{140}$ Stratas, "A Decade of Dunsmuir," supra note 10.

${ }^{141}$ Bibeault, supra note 14, Beetz J (endorsing the proposition that "[t]o a large extent, judicial review of administrative action is a specialized branch of statutory interpretation" at para 120, citing SA de Smith, Constitutional and Administrative Law, 4th ed (Harmondsworth, UK: Penguin Books, 1981) at 558.

142 This "margin of appreciation" approach is explained as the sole question of judicial review in Matthew Stephenson \& Adrian Vermeule, "Chevron Has Only One Step" (2009) 95 Va L Rev 597.
} 
"jurisdictional question" is really a question of legislative interpretation, one calling for reasonableness review on the basis of all of the above authorities.

Put another way, the issue whether an administrative tribunal is inside or outside the "jurisdictional" fences set up by Parliament is really an issue of where those fences are - in other words, an interpretation of what the legislation says about what the administrative decision-maker can or cannot do. ${ }^{143}$

This illustrates the basic problem: all determinations by a decision-makerwhether jurisdictional or not-are simply products of the statutory grant. When a decision-maker has a matter before it on which it must rule, it will interpret its statute to determine whether it gives the decision-maker jurisdiction. Therefore, there is no principled basis to carve out a separate jurisdictional questions category.

Other countries have similarly come to this conclusion. For example, in the United States, the doctrine of jurisdictional questions no longer exists. In City of Arlington, ${ }^{144}$ Justice Scalia for the majority first considered the distinction, accepted by the Guerin dissenters, between "big, important" interpretations going to jurisdiction, and other "humdrum, run-of-the-mill stuff." $145 \mathrm{He}$ also indicated the analytical problem with "jurisdiction" as a separate category:

That premise is false, because the distinction between "jurisdictional" and "nonjurisdictional" interpretations is a mirage. No matter how it is framed, the question a court faces when confronted with an agency's interpretation of a statute it administers is always, simply, whether the agency has stayed within the bounds of its statutory authority." 146

Justice Scalia followed this paragraph by noting that, because administrative decision-makers are creatures of statute, "[b]oth their power to act and how they are to act is authoritatively prescribed by Congress, so that when they act improperly, no less than when they act beyond their jurisdiction, what they do is ultra vires." ${ }^{147}$ In other words, whether a decision-maker makes an error that is a simple legal error or a jurisdictional one, it has gone beyond its statutorily granted powers. On this account, Justice Scalia concludes that "there is no principled basis for carving out some arbitrary subset of such claims as "jurisdictional." 148

${ }^{143}$ Canadian Copyright Licensing Agency (Access Copyright) v Canada, 2018 FCA 58 at paras 57-58 [Access Copyright].

${ }^{144}$ City of Arlington v Federal Communications Commission, 569 US 290 (2013) [City of Arlington].

${ }^{145}$ Ibid at 297.

${ }^{146}$ Ibid (emphasis in original).

147 Ibid.

${ }^{148}$ Ibid at 298. 
City of Arlington is a prime example of the policing function without the myth of jurisdictional questions. This is not a foreign case for our purposes; as noted above, the Supreme Court of Canada has recognized the need for courts to enforce the boundaries of the administrative state, having regard to the fundamentally statutory character of administrative decision-makers. If courts faithfully enforce statutory boundaries, there is no tension between the rule of law and legislative supremacy. Instead, these important principles are reconciled without the fruitless search for a myth.

The policing function therefore finds more in common with Bibeault than Dunsmuir. Under Bibeault, there was some analytical similarity between the various sorts of legal determinations that a decision-maker must make. All legal errors went to the general "jurisdiction" of a decision-maker, including jurisdiction narrowly described as well as broader legal errors. But in Bibeault, the general "jurisdiction" of the decisionmaker is its statutory authority, in the terms described in City of Arlington and Access Copyright. Bibeault is authority that courts should recognize that all errors in administrative law are fundamentally statutory, whether they are jurisdictional or not.

Before turning away from the myth, it is important to deal with the criticism from the grounds of the rule of law advanced by some judges on the Supreme Court, particularly in Guerin and CHRC. Without the jurisdictional questions category, so the argument goes, courts abdicate their role to ensure that administrative decision-makers stay within their statutory boundaries under the rule of law. If courts do not have the last word on jurisdictional matters, administrative decision-makers have the final word on their own limits. Put this way, serious rule of law concerns abound.

The most relevant case grounding this criticism is Crevier. As alluded to above, Crevier held that while legislatures could immunize their decisions from review on legal grounds, they could not do so on jurisdictional grounds. ${ }^{149}$ This was framed by the court as a constitutional principle, derived from section 96 of the Constitution Act, 1867.150 Then, later, the $C H R C$ dissenters used Crevier to opine that the rule of law requires the jurisdictional questions correctness category. ${ }^{151}$

There are two related retorts to this position that come from the perspective of the rule of law. The first is that there is no authority for the idea that the rule of law requires a category of jurisdictional questions that invite a separate standard of review. As noted in City of Arlington, an error in jurisdiction plays a separate role in administrative law than in other areas of law. In administrative law, "[a] decision maker may not exercise authority not specifically assigned to him or her." 152 Administrative decision-makers owe their existence wholly to statute and have no inherent jurisdiction beyond the enabling

\footnotetext{
${ }^{149}$ Crevier, supra note 14 at 236-37.

${ }^{150}$ Ibid.

${ }^{151}$ CHRC, supra note 105 at para 77.

${ }^{152}$ Dunsmuir, supra note 3 at para 29.
} 
statute. It follows that, through ordinary statutory amendment, administrative powers can be significantly limited or curtailed completely. Neither the Constitution nor the rule of law requires the administrative state.

As a corollary, the basic power to hear and decide cases underlies the "jurisdictional questions" category in administrative law. In Dunsmuir, the court spoke of jurisdiction as simply the "authority to make the inquiry." ${ }^{153}$ A decision-maker must "explicitly determine whether its statutory grant of power gives it the authority to decide a particular matter." 154 In administrative law, then, the power to hear and decide cases is not constitutionally prescribed but rather is a function of statutory interpretation. This flows from the simple fact that administrative decision-makers are statutory creatures.

In contrast, section 96 courts under the Constitution Act, 1867 do have constitutionally recognized inherent jurisdiction, which means that the core of this jurisdiction cannot be abrogated by ordinary legislation. ${ }^{155}$ The core of the jurisdiction includes the power to hear and decide cases on certain matters. For example, if Parliament proposed to "transfer the present Superior Courts' jurisdiction to try indictable offences to a provincial court," such a transfer would be unconstitutional; it would deprive the Governor-General of her appointing power under section 96 of the Constitution Act, $1867 .^{156}$

In the section 96 context, jurisdiction has a specific meaning that denotes constitutional significance. But the Guerin dissenters imply that the rule of law requires a court, as a matter of constitutional law, to impose that same significance to the term "jurisdiction" in relation to administrative decision-makers. That same significance cannot be transferred to the administrative law context, where decision-makers interpret their enabling statutes to determine both whether they have authority to hear the case and then to determine the merits of the matter. All matters a decision-maker must determine, if Dunsmuir is correct, are functions of the grant of authority given to it by the legislature. The rule of law does not require greater scrutiny on one type of legal error over the other.

The second retort to this criticism is found in City of Arlington. There, Justice Scalia noted that in every case, the question is only about the rigorous enforcement of statutory boundaries on either jurisdictional or non-jurisdictional grounds. The rule of law concern would arise if administrative decision-makers could opine conclusively on any legal matter, not only matters of jurisdiction. But as noted above, the Supreme Court of Canada has accepted that this is constitutionally impossible. There is no principled reason to be concerned about a decision-maker determining its jurisdiction as compared to any other legal error so long as the court rigorously enforces legislative language in each case.

\footnotetext{
${ }^{153}$ Dunsmuir, supra note 3 at para 59.

154 Ibid.

${ }^{155}$ MacMillan Bloedel, supra note 39.

${ }^{156}$ See McEvoy, supra note 38 at 720.
} 
The same logic applies in the Canadian context. The imposition of an artificial category of "jurisdictional questions" ignores the fact that jurisdictional provisions and other legal provisions are all statutory provisions. By imposing a separate category of review for jurisdictional provisions, there is a possibility that a court may intervene when Parliament mandates deference in statutory language. At the same time, the rule of law does not require a separate category of jurisdictional questions. All it requires is that courts enforce statutory boundaries, whether jurisdictional or not. If this is the case, the category is unhelpful and distracting in the doctrine of judicial review.

Similar to the expertise category, the jurisdictional questions category creates distortions in the law of judicial review. Courts overstep their constitutional bounds by interfering with statutorily-empowered decision-makers. The maintenance of the category harkens back to the pre-CUPE days of jurisdiction, where the category was a doctrinal black hole that sucked all questions of law into its orbit. Under this rubric, decision-makers who otherwise would be given a wide breadth of deference are subject to judicial intervention on the basis of a court-created category-one that can be easily manipulated or misapplied. The effect is unwarranted judicial interference in otherwise lawful administrative action. This is contrary to the principle "won four centuries ago at the cost of much bloodshed": that of legislative supremacy. ${ }^{157}$

\section{CONCLUSION}

The law of judicial review, soon to be revisited in the consolidated appeals to the Supreme Court, presents an opportunity for the court to get back to the basics of judicial review. The baseline reconciliation of legislative supremacy and the rule of law is present in the policing function, which asks courts to vindicate the rule of law by authentically applying the decision-maker's enabling statute to its decisions. The implication of this approach requires no standard of review analysis, nor any categories of "reasonableness" or "correctness." Deference is simply a function of statutory boundaries.

The myths of judicial review are premised on the standard of review categories. Expertise is typically marshalled as a reason for a reasonableness standard of review. The category of jurisdictional questions typically involves review for correctness. The fact that these factors almost always lead to a particular standard of review ignores the varied nature of statutory contexts in administrative law. Put differently, legislatures have the power to specify a standard of review in legislative language, to which courts must give effect. By binding their decisions to categories and factors outside the statute, courts abdicate the policing function.

${ }^{157}$ Williams, supra note 45 at para 49. 